\title{
Recurrent Ureter Carcinoma
}

National Cancer Institute

\section{Source}

National Cancer Institute. Recurrent Ureter Carcinoma. NCI Thesaurus. Code C9255.

The reemergence of ureter carcinoma after a period of remission 